\title{
Under scrutiny, India's medical research council faces review
}

BANGALORE, INDIA - A high-powered panel set up at the request of India's Ministry of Finance is reviewing the work of the Indian Council of Medical Research (ICMR), the country's primary funding and coordinating body for biomedical research, based in New Delhi.

The ICMR has faced criticism that the medical research it supports does not adequately address public health problems. Such critiques, it seems, have prompted the ministry to seek an external audit of the ICMR's research programs before the government releases the 85 billion rupees ( $\$ 1.6$ billion) that the council has asked for over the next five years-twice as much as it got for the previous five years-including 31.5 billion rupees for new scientific institutes and an upgrade of existing ones.

Prakash Tandon, a neurosurgeon at the government-funded National Brain Research Centre in New Delhi who heads the 11-member committee, told Nature Medicine that a new direction for medical research will be formulated after critical evaluation of the usefulness and public health relevance of programs in each of the ICMR's 27 institutes. It's likely that a number of duplicated programs across different ICMR institutes will be recommended for closure, added pathologist Indira Nath, an emeritus professor at the National Institute of Pathology in New Delhi and a committee member. The review of the ICMR began in February, and a report was slated to be filed late last month, as this issue went to press.

The ICMR, India's equivalent of the US National Institutes of Health, grew out of the Indian Research Fund Association, which was founded in 1911 when the country was under British rule. The scientific body was restructured and designated under its current name in 1949, two years after India gained independence. However, its recent progress has come under scrutiny.

The 12th five-year plan document, released late last year by India's Planning Commission, the apex body chaired by the Prime Minister that formulates fiveyear plans and allocates money for various ministries, stated that "health research in India has yet to make a major impact" on public health, noting that the nation bears a high proportion of the global burden of diseases such as tuberculosis and leprosy. The infant mortality rate is also still high (44 per 1,000 births), as is the prevalence of anemia and malnutrition.

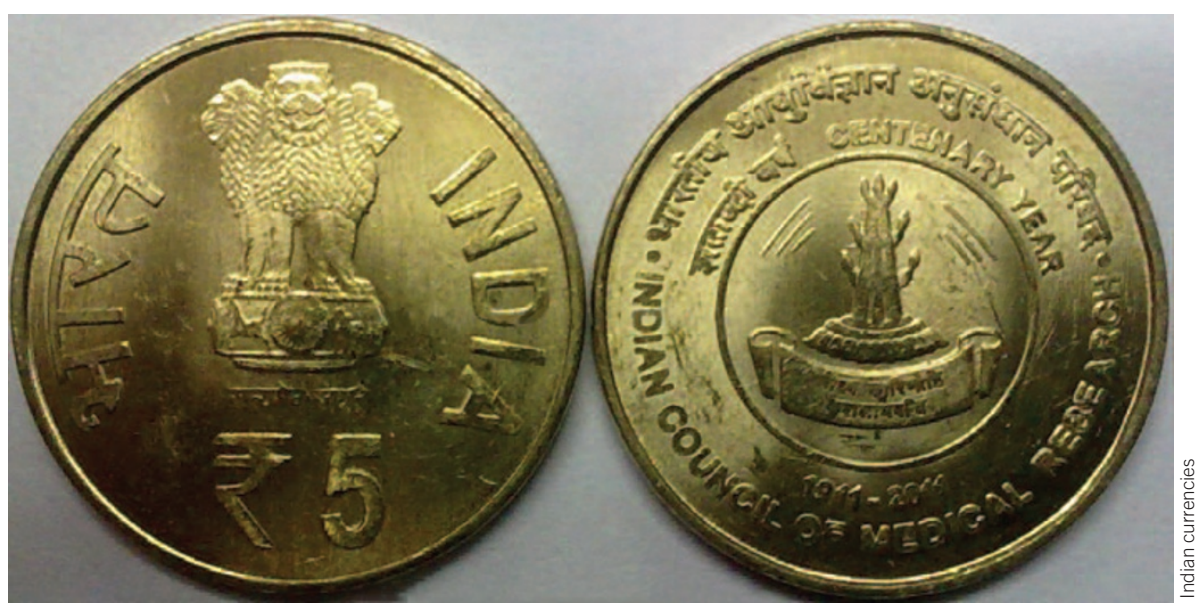

Losing luster: The ICMR, celebrated with commemorative coins, faces criticisms.

"Recurrent epidemics of Japanese encephalitis, Dengue and Chikungunya continue to haunt India," says Payyalore Rajagopalan, former director of the ICMR's Vector Control Research Centre in Pondicherry. Rajagopalan explains that he resigned from the committee advising the ICMR on malaria research after he found that the agency "was not keen on a long-term objective and was happy carrying out fire-fighting operations during epidemics apart from conducting meetings and producing reports and recommendations." The Tandon-led committee, he says, is simply "another bureaucratic exercise."

\section{Lowered expectations}

Kalyan Banerjee, former director of ICMR's National Institute of Virology in Pune, agrees. "We cannot expect too much from this review," he told Nature Medicine. "Each ICMR institute has a [scientific advisory committee] that meets every year, and if the ICMR translates the [committee's] recommendations into action, where is the need of an inquiry by external experts who may not have the solutions for the ICMR's problems?"

Vishwa Mohan Katoch, ICMR director general, declined to speak to Nature Medicine, but the agency's former chief Gowdagere Satyavati points out that the ICMR alone cannot be blamed for poor impact on public health. "There are other organizations in the health ministry for health delivery, and don't forget that health is a state subject," she says. "The central government formulates programs, but the states must implement them."

Beyond the review, the ICMR has also faced scrutiny amidst corruption allegations.
On 14 February, the Central Bureau of Investigation (CBI) arrested several of the research agency's current and former officials on charges of corruption and misuse of official position in a land scam.

The CBI had launched the investigation after purported misdealings were exposed in 2009 by the government's audit body, the Comptroller and Auditor General of India. According to the auditor, top officials illegally transferred the land belonging to one of the ICMR institutes to a private housing society at a fraction of its market price, causing huge loss to the government. Media reports have quoted the accused officials as vigorously denying the charges against them. If convicted, the officials could be jailed for up to seven years." to "If convicted, the officials could face up to seven years in prison.

Killugudi Jayaraman

\section{Corrections}

In the December 2012 issue, the article entitled "Storm shows need for mouse backup, but costs present challenges" (Nat. Med. 18, 1724, 2012) incorrectly referred to the price of freezing per embryo as $\$ 1,000$ to $\$ 4,000$, when in fact this cost refers to the price of freezing per mouse line. The error has been corrected in the HTML and PDF versions of the article.

In the February 2013 issue, the article entitled "Amgen deal triggers watchful waiting in targeted nanomedicine" (Nat. Med. 19, 120, 2013) incorrectly referred to the drug docetaxel as decoxtel. The error has been corrected in the HTML and PDF versions of the article. 